\title{
Effects of Mixed Dietary Fats on the Distribution of Triglycerides in Different Tissues of Exercised Trained Swiss Albino Mice
}

\author{
Shaikh Shahinur Rahman1*, Mohammad Ayub Ali2, Mohammad Nazibur Rahman ${ }^{3}$ \\ ${ }^{1}$ Department of Applied Nutrition and Food Technology, Islamic University, Kushtia, Bangladesh \\ ${ }^{2}$ Paediatrics, General Hospital, Kushtia, Bangladesh \\ ${ }^{3}$ Department of Biochemistry and Molecular Biology, Jahangir University, Savar, Dhaka, Bangladesh \\ Email: "shahinanft@gmail.com
}

Received 22 October 2015; accepted 7 November 2015; published 13 November 2015

Copyright (C) 2015 by authors and OALib.

This work is licensed under the Creative Commons Attribution International License (CC BY).

http://creativecommons.org/licenses/by/4.0/

(c) (i) Open Access

\begin{abstract}
During prolonged exercise, fatty acids are mobilized from triglycerides (TG) and become an important energy source. But excess accumulation of TG in different tissues causes abnormalities in humans. Role of high fat diet in the distribution of TG is well established but the role of mixed dietary fat is not clear. In our study, exercised Swiss Albino mice were subjected to feed high fat diet and mixed fat diet (Saturated + Unsaturated fat enriched diet) for the period of four weeks to show the effect on average body weight, liver, adipose tissue and gastrocnemius muscles and the accumulation of their triglycerides (TG) content. This study showed that both diets had little or no effect on average body weight, epididymal adipose tissue weight and liver TG but decreased liver weight. Here another remarkable feature was that high fat diet significantly reduced the accumulation of TG in epididymal adipose tissue in comparison with mixed fat diet. The author demonstrated that mixed fat diet induced accumulation of TG in gastrocnemius skeletal muscles of exercised mice but decreased gastrocnemius skeletal muscles weight. Further research is required to clarify these phenomena.
\end{abstract}

\section{Keywords}

Triglycerides, Liver, Working Muscle, Adipose Tissue, Exercise, Mixed Diet, Swiss Albino Mice

Subject Areas: Food Science \& Technology, Nutrition

\footnotetext{
${ }^{*}$ Corresponding author.
}

How to cite this paper: Rahman, S.S., Ali, M.A. and Rahman, M.N. (2015) Effects of Mixed Dietary Fats on the Distribution of Triglycerides in Different Tissues of Exercised Trained Swiss Albino Mice. Open Access Library Journal, 2: e2113. 


\section{Introduction}

Carbohydrate and fatty acid (FA) are the major energy sources for working muscles. During exercise, when carbohydrate sources are depleted, oxidation of fatty acids plays an important role in producing energy [1] [2]. Reduced physical activity and high fat diet promote excessive deposition of fat [3]-[5]. Excess accumulation of TGs in various tissues like adipose tissue, liver, muscle, heart etc. can cause abnormalities (e.g. obesity, insulin resistance, hyperlipidemia etc.) in humans [6]-[8]. It is well established that accumulation of intramuscular TGs is inversely associated with insulin action [9]-[13]. Rats fed a diet high in saturated fats and/or subjected to prolonged inhibition of fatty acid oxidation initiates intramuscular TG accumulation and insulin resistance (IR) [9]. On the other hand, long-chain n-3 polyunsaturated fatty acids (LC n-3 PUFA), such as docosahexaenoic acid (DHA; 22:6n-3) and eicosapentaenoic acid (EPA; 20:5n-3), help to reduce TG content in humans [14] [15]. Omega-3 polyunsaturated fatty acid rich diet causes hypolipidemia [16] [17] but sometimes it may alter lipid metabolism, thus it may also support lipid deposition. On the other hand, omega-6-rich diet with a small amount of eicosapentaenoic and docosahexaenoic polyunsaturated fatty acids improves the circulating lipid profile, but it does not prevent excess liver lipid accumulation [18]. A few studies in the rat comparing the effects of feeding Medium-chain triglyceride (MCT) and long-chain triglyceride (LCT) diets [19]-[22] have provided evidence that MCT diets lead to less deposition of body fat than LCT diets. It is well proved that high fat diet is an important biomarker for obesity [23] and it is also the main cause of hepatocellular necrosis formation on liver [24]. Skeletal muscle triacylglycerols (TG) also act as an important lipid pool. A negative correlation was found between intramuscular TG content and insulin sensitivity in rats and in humans. A high fat diet also induced insulin resistance [25]. Physical exercise, especially prolonged exercise training, enhances insulin sensitivity and helps to inhibit the accumulation of TG in various tissues. Accumulation of adipocyte fat could not be protected in previously exercise trained rats although they fed with standard or high fat diet (HFD) [26]. Compared with freshly inactive and sedentary rats fed with HFD, higher body adiposity is observed in previously trained rats that have been inactive for a while [27]. However, it remains unclear whether TG content changes among various tissues upon addition of mixed triglycerides to normal diet in random exercised mice. The aim of the present study is to investigate triglycerides content in various tissues in three groups of exercise trained mice- Normal diet (control), Saturated + Unsaturated fat enriched diet and Unsaturated + Unsaturated fat enriched diet.

\section{Methods}

\subsection{Animals}

Swiss albino mice were collected from Animal House, Icddr'b, Dhaka, Bangladesh. The age of these mice was 6 (six) weeks and the average initial body weight was approximately $27.2 \mathrm{~g}$. Mice were housed in a cage in a temperature-controlled room at $23^{\circ} \mathrm{C}$ with a $12: 12$-h light-dark cycle. These mice were divided into 3 groups: one group was taken as control group and others were high fat diet group and mixed fat diet group (each group contain eight mice in which four mice were male and four were female). All groups of mice were fed a balanced diet (purchased from Animal House, Icddr'b, Dhaka, Bangladesh) and the experimental group's diet were mixed with saturated and unsaturated fatty acids like ghee, soybean and tisi. Body weight and food intake were measured at regular intervals throughout the feeding intervention i.e. four weeks. Duration of treadmill exercise also recorded regularly. All experiments conducted in this study were approved by the Animal Care Committee of the Faculty of Science and Technology, Islamic University, Bangladesh.

\subsection{Diet}

The composition of normal or balanced diet for both mice was: Wheat flour $(30 \%)$, Wheat bran $(21 \%)$, Rice polish (20\%), Protein source (Fish-meal) (10\%), Oilseed cake (10\%), Molasses (5\%), Soybean oil (2\%), Common salt $(1.5 \%)$ and Vitamins $(0.5 \%)$. The experimental diets were normal diet mixed with $5 \mathrm{~g}$ saturated and unsaturated fatty acids/day.

\subsection{Exercise Protocol}

All mouse (both control and experimental) were exercised regularly through a rolling treadmill in the laboratory. From the beginning (first week), they were exercised $5 \mathrm{~min} /$ day and next $2^{\text {nd }}, 3^{\text {rd }}$ and $4^{\text {th }}$ week this exercise session were $6 \mathrm{~min} /$ day, $7 \mathrm{~min} /$ day and $8 \mathrm{~min} /$ day respectively. 


\subsection{Anatomical Procedure and Tissues Sampling}

After four weeks observation, the mice were analyzed. The mice were anesthetized with an intraperitoneal injection of pentobarbital sodium ( $5 \mathrm{mg} / 100 \mathrm{~g}$ body weight; Abbott, IL, USA). Tissues (Liver, Adipose tissues and skeletal muscles) were sectioned and after wrapping with aluminum foil, tissues were stored at $-20^{\circ} \mathrm{C}$.

\subsection{Biochemical Measurements}

Triglycerides of different tissues (adipose tissue, liver \& skeletal muscle) were measured using commercial kits through following standard method. All this experiments were done at the laboratory of the Applied Nutrition \& Food Technology of Islamic University, Kushtia.

\subsection{Determination (Procedure) of TG Content in Tissues}

TG contents within tissues were determined by following a standard protocol (Chul-Hee et al., 2003). Briefly, certain amount of tissues $(\sim 25 \mathrm{mg})$ were extracted with $\mathrm{CHCl}_{3} / \mathrm{CH}_{3} \mathrm{OH}(1: 2 \mathrm{vol} / \mathrm{vol})$ and homogenized. Homogenates were centrifuged at $1500 \mathrm{rpm}$ for 30 minutes at $4^{\circ} \mathrm{C}$, washed with $500 \mu \mathrm{L}$ ice-cold phosphate buffered saline (PBS) and centrifuged as above. After the addition of $2 \mathrm{ml} \mathrm{H}_{2} \mathrm{SO}_{4}$, the tubes were vortexed and centrifuged at $1500 \mathrm{rpm}$ for 10 minutes at $4^{\circ} \mathrm{C}$. The upper phase was discarded, and $100 \mathrm{mg} \mathrm{Na} \mathrm{S}_{2} \mathrm{O}_{3}$ was added to the lower phase. The samples were vortexed and centrifuged at $1500 \mathrm{rpm}$ for 5 minutes at $4^{\circ} \mathrm{C}$. The upper phase was removed, and the lower phase was evaporated under $\mathrm{N}_{2}$. The samples were dissolved with $70 \%$ isopropanol for 10 seconds, and then TG was measured in triplicate using a commercial kit (GPO-POD. Liquid kit; Atlas Medical; Unit 4, William James House, Cowley Rd, Cambridge, CB4 OWX).

\subsection{Calculation of GPO-POD Method}

$$
\frac{(A) \text { Sample }}{(A) \text { Standard }} \times 200(\text { Standard conc. })=\mathrm{mg} / \mathrm{dl}
$$

Triglyceride in the sample.

Conversion factor: $\mathrm{mg} / \mathrm{dl} \times 0.0113 \mathrm{mmol} / \mathrm{l}$.

\subsection{Data Analysis}

Values represent the mean \pm SE. The significance of differences between means was assessed by the Scheffe test after analysis of variance had been performed to establish that there were significant differences between the groups.

\section{Results}

In this study, Figure 1 showed that there was no change in body weight when both saturated ghee or unsaturated soybean were mixed with another more unsaturated dietary fat tisi. Whereas, Figure 2 represents that both saturated ghee and unsaturated soybean accompanied with more unsaturated tisi decreased liver weight in exercise trained mice.

Figure 3 also represents that only tisi together with soybean but not tisi with ghee decreased gastrocnemius muscle weight in exercise trained mice. Neither saturated nor unsaturated dietary fats could change epididymal adipose tissue weight (Figure 4).

Figure 5 also showed that both saturated and unsaturated dietary fats could not change liver triglycerides content in the exercise trained mice. Whereas, Figure 6 depicts that tisi together with saturated or unsaturated dietary fat decreased triglycerides content in the epididymal adipose tissue of exercise trained mice. Here another remarkable feature is that TG in the adipose tissue decreased significantly in tisi plus ghee group of mice compared to tisi plus soybean (Figure 6). Only tisi together with soybean but not tisi with ghee increased gastrocnemius muscle weight significantly in exercise trained mice (Figure 7).

\section{Discussion}

For many years it has been debated whether triacylglycerols located in the muscle are utilized during exercise 


\section{Body weight}

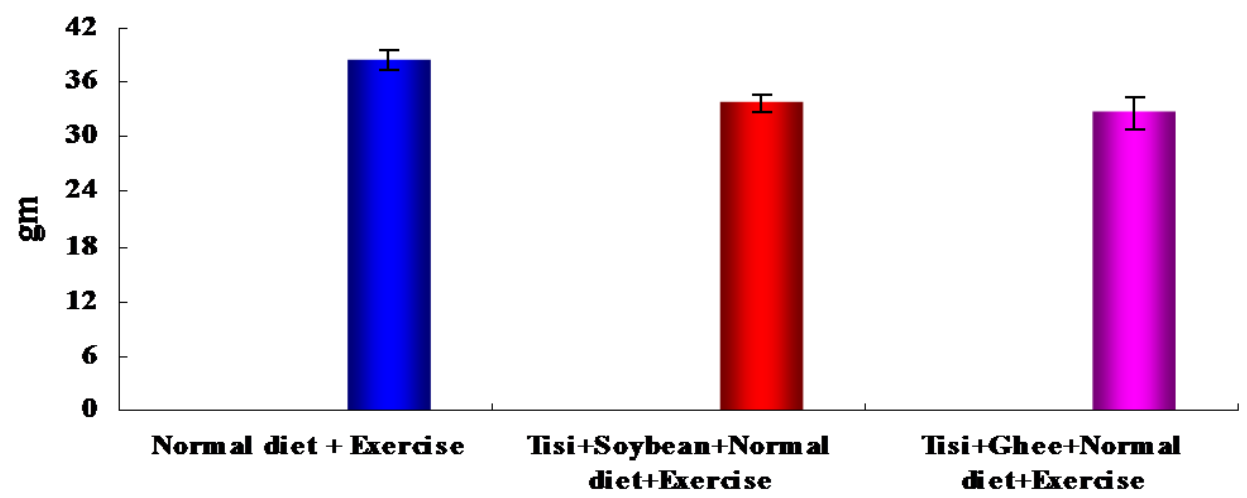

Figure 1. Effects of mixed dietary fat on the body weight of Swiss albino mice. Body weight from Normal diet (control), Ti$\mathrm{si}+\mathrm{Ghee}+$ Normal diet (experimental) and Tisi + Soybean + Normal diet (experimental) consumed mice were measured. The bar graphs represent the body weight of three groups; data are expressed as mean \pm SEM. ${ }^{*} P<0.05$ or less vs. Control.

\section{Liver weight}

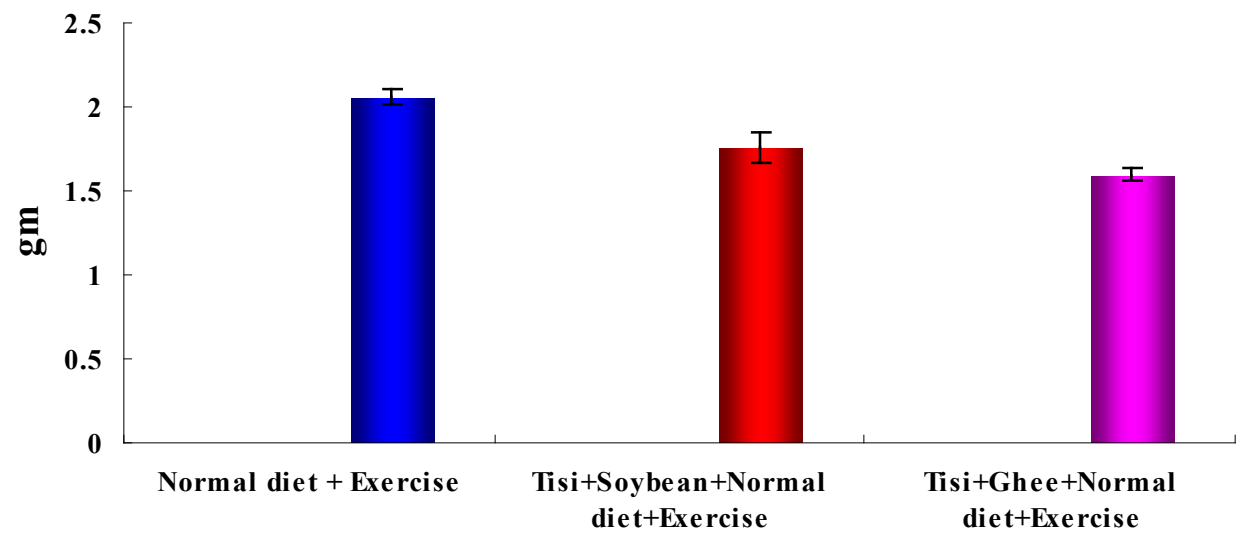

Figure 2. Effects of mixed dietary fat on the liver weight of Swiss albino mice. Liver weight from Normal diet (control), Tisi + Ghee + Normal diet (experimental) and Tisi + Soybean + Normal diet (experimental) consumed mice were measured. The bar graphs represent the liver weight of three groups; data are expressed as mean $\pm \mathrm{SEM}^{*} P<0.05$ or less vs. Control.

\section{Gas trocne mius muscle weight}

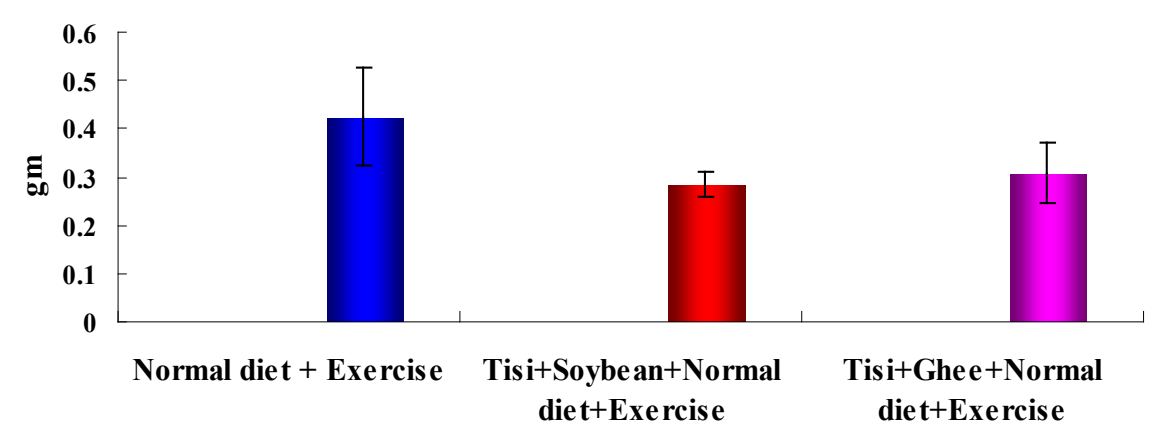

Figure 3. Effects of mixed dietary fat on the gastrocnemius muscle weight of swiss albino mice. Muscle weight from Normal diet (control), Tisi + Ghee + Normal diet (experimental) and Tisi + Soybean + Normal diet (experimental) consumed mice were measured. The bar graphs represent the gastrocnemius weight of three groups; data are expressed as mean \pm SEM. ${ }^{*} P<0.05$ or less vs. Control. 


\section{Epididymal adipose tissue weight}

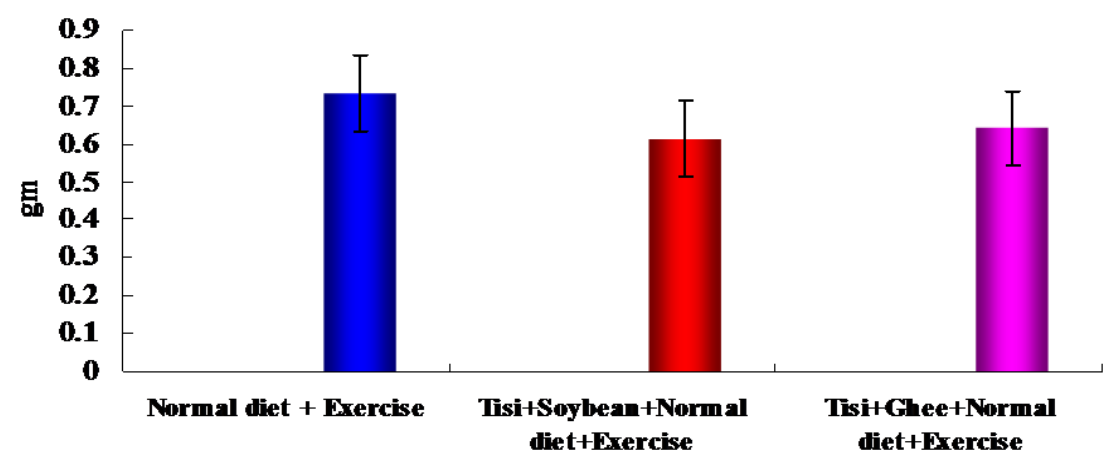

Figure 4. Effects of mixed dietary fat on the epididymal adipose tissue weight of swiss albino mice. Adipose weight from Normal diet (control), Tisi + Ghee + Normal diet (experimental) and Tisi + Soybean + Normal diet (experimental) consumed mice were measured. The bar graphs represent the adipose weight of three groups; data are expressed as mean \pm SEM. ${ }^{*} P<$ 0.05 or less vs. Control.

\section{Liver TG}

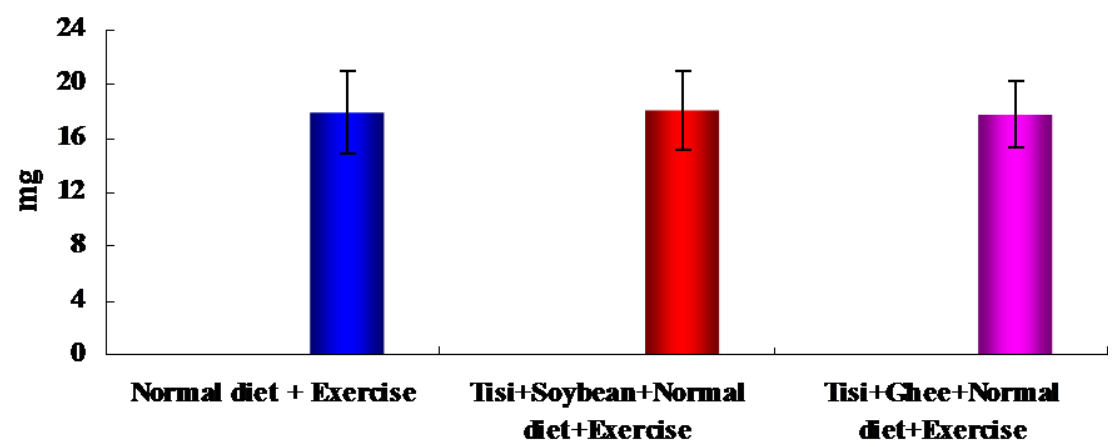

Figure 5. Effects of mixed dietary fat on triglyceride content in liver of swiss albino mice. Liver TG from Normal diet (control), Tisi + Ghee + Normal diet (experimental) and Tisi + Soybean + Normal diet (experimental) consumed mice were measured. The bar graphs represent the liver TG content of three groups; data are expressed as mean \pm SEM. ${ }^{*} P<0.05$ or less vs. Control.

\section{Epididymal adipose tissue TG}

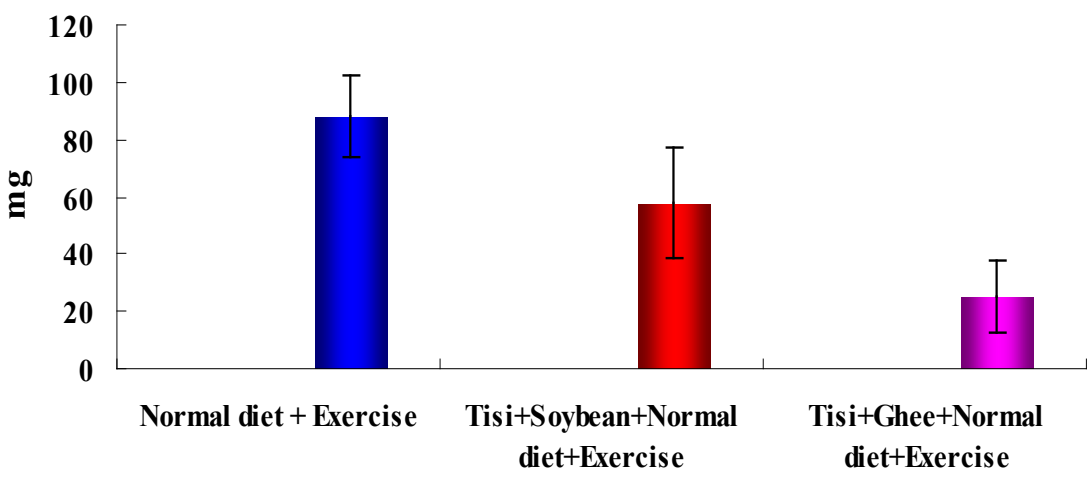

Figure 6. Effects of mixed dietary fat on triglyceride content in the epididymal adipose tissue of swiss albino mice. Epididymal adipose TG from Normal diet (control), Tisi + Ghee + Normal diet (experimental) and Tisi + Soybean + Normal diet (experimental) consumed mice were measured. The bar graphs represent the epididymal adipose TG content of three groups; data are expressed as mean \pm SEM. ${ }^{*} P<0.05$ or less vs. Control. 


\section{Gastrocnemius muscle TG}

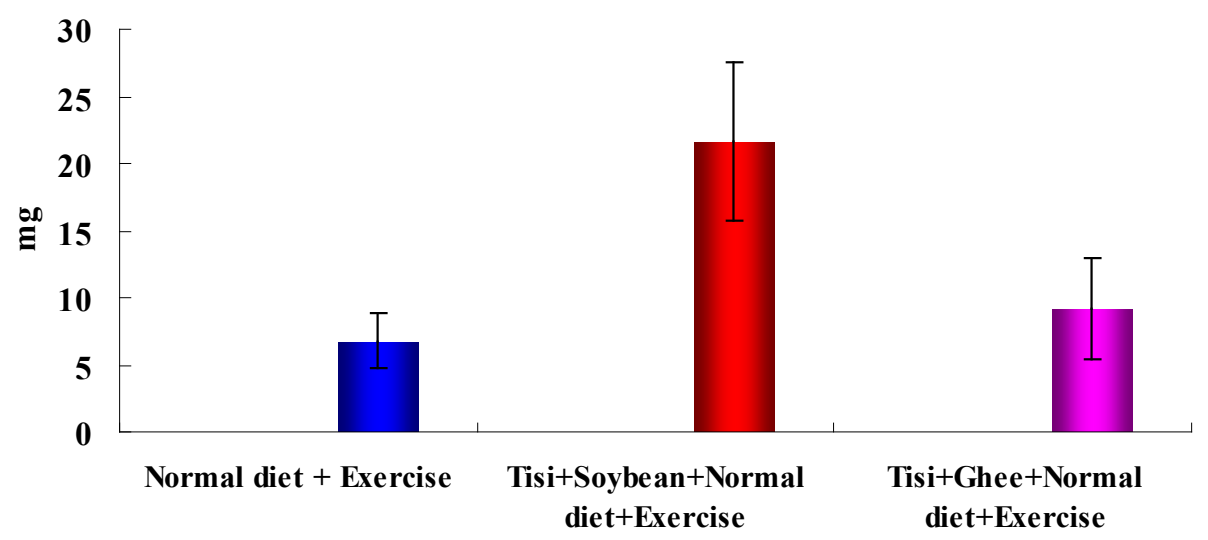

Figure 7. Effects of mixed dietary fat on triglyceride content in the gastrocnemius muscle of swiss albino mice. Gastrocnemius muscle TG from Normal diet (control), Tisi + Ghee + Normal diet (experimental) and Tisi + Soybean + Normal diet (experimental) consumed mice were measured. The bar graphs represent the gastrocnemius TG content of three groups; data are expressed as mean \pm SEM. $^{*} P<0.05$ or less vs. Control.

[28] because conflicting results have been appeared. The main reason for these contradict result is the intensity of exercise and its duration. It also depends on training status i.e. trained or untrained. To interpret the role of intramuscular triglyceride (IMTG) as a potential energy source during exercise, these matters have to be taken into consideration. It is controversial whether IMTG hydrolysis and utilization during exercise is increased by training. Only a few studies have been demonstrated by applying muscle biopsy technique i.e. trained rats have higher IMTG utilization during the absolute intensity exercise in compared with the untrained situation whereas other studies were unable to obtain a training-induced increase in IMTG utilization in males or in females at the same absolute or relative work load. A lot of factors are responsible for the accumulation of lipid in the liver but hepatic insulin resistance may be an important factor for the development of hepatic lipid accumulation. So, exercise has a potential effect on regulating/preventing hepatic lipid accumulation [29].

Several scientists have studied the effects of high fat diet with random exercise upon the body triglycerides In most cases, high concentration of lipid was deposited in the skeletal muscle, lipid or adipose tissue [30] [31]. The predominant causes for lipid deposition were lifestyle modification, lack of exercise, chronic over consumption of calories coupled with deleterious intakes of saturated or trans-unsaturated fatty acids or insulin resistance [31]. However, it remains unclear about the fate of TG concentration among the various tissues when mixed dietary fats are added to normal diet in random exercised mice. Therefore the aim of the present study is to investigate triglycerides content in various tissues in three groups of exercise trained mice-Normal diet (control), Saturated + Unsaturated fat enriched diet and Unsaturated +Unsaturated fat enriched diet. The experiment was designed with Swiss Albino mice subjected to random exercise for 4 weeks and fed high fat diet. One group was named control group which received normal diet. The mixed fat diet was of two kinds - soybean plus tisi and ghee plus tisi. After 4 weeks of exercise training the weight of the body, liver, adipose tissue and skeletal muscles were measured from the three groups of mice. Triglyceride content from liver, epididymal adipose tissue and gastrocnemius skeletal muscles were also measured from the same groups of mice.

As seen in the present study, body weight undergoes no alteration owing to the effect of neither saturated ghee nor unsaturated soybean when used with another more unsaturated dietary fat tisi. Both saturated ghee and unsaturated soybean accompanied with more unsaturated tisi decreased liver weight in exercise trained mice. Only tisi together with soybean but not tisi with ghee decreased gastrocnemius muscle weight in exercise trained mice. Neither saturated nor unsaturated dietary fats could change epididymal adipose tissue weight in the exercise trained mice. Neither saturated nor unsaturated dietary fats could change liver triglycerides content in the exercise trained mice. Tisi together with saturated or unsaturated dietary fat decreased triglycerides content in the epididymal adipose tissue of exercise trained mice. Here another remarkable feature is that TG in the adipose tissue decreased significantly in tisi plus ghee group of mice compared to tisi plus soybean. Only tisi together with soybean but not tisi with ghee increased gastrocnemius muscle weight significantly in exercise trained mice. 


\section{Conclusion}

The author demonstrates that mixed TG induces accumulation of TG in both epididymal adipose tissue and gastrocnemius skeletal muscles of exercise trained mice. The weight of skeletal muscle increased but weight of adipose remained unaltered. Although no TG accumulation occurred in liver of exercise trained mice, weight increased significantly. Further research is required to clarify these phenomena.

\section{Acknowledgements}

This research study was supported by the Faculty of Science \& Technology, Islamic University, Kushtia, Bangladesh. The authors are thankful to the Dept. of Applied Nutrition and Food Technology for their support providing laboratory facilities and logistic support to carry out this research work.

\section{Conflicts of Interest}

The author(s) declare(s) that there is no conflict of interest regarding the publication of this manuscript.

\section{References}

[1] Kiens, B. (2006) Skeletal Muscle Lipid Metabolism in Exercise and Insulin Resistance. Physiological Reviews, 86, 205-243. http://dx.doi.org/10.1152/physrev.00023.2004

[2] Spriet, L.L. and Watt, M.J. (2003) Regulatory Mechanisms in the Interaction between Carbohydrate and Lipid Oxidation during Exercise. Acta Physiologica Scandinavica, 178, 443-452. http://dx.doi.org/10.1046/j.1365-201X.2003.01152.x

[3] Piscitelli, F., Carta, G., Bisogno, T., Murru, E. and Cordeddu, L. (2011) Effect of Dietary Krill Oil Supplementation on the Endocannabinoidome of Metabolically Relevant Tissues from High Fat-Fed Mice. Nutrition \& Metabolism, 8, 51. http://dx.doi.org/10.1186/1743-7075-8-51

[4] Tandy, S., Chung, R.W., Wat, E., Kamili, A. and Berge, K. (2009) Dietary Krill Oil Supplementation Reduces Hepatic Steatosis, Glycemia, and Hypercholesterolemia in High-Fat-Fed Mice. Journal of Agricultural and Food Chemistry, 57, 9339-9345. http://dx.doi.org/10.1021/jf9016042

[5] Bracco, E.F., Torbay, N., Geiebter, A., Stewart, I., Seylar, J. and Hashim, S.A. (1980) Insulin Increases Body Fat with Control of Food Intake and Physical Activity. Alimentary Nutrition \& Metabolism, l, 234.

[6] Nishino, N., Tamori, Y., Tateya, S., Kawaguchi, T., Shibakusa, T., Mizunoya, W., Inoue, K., Kitazawa, R., Kitazawa, S., Matsuki, Y., et al. (2008) FSP27 Contributes to Efficient Energy Storage in Murine White Adipocytes by Promoting the Formation of Unilocular Lipid Droplets. Journal of Clinical Investigation, 118, 2808-2821.

[7] Hotamisligil, G.S., Budavari, A., Murray, D. and Spiegelman, B.M. (1994) Reduced Tyrosine Kinase Activity of the Insulin Receptor in Obesity-Diabetes: Central Role of Tumor Necrosis Factor-Alpha. Journal of Clinical Investigation, 94, 1543-1549. http://dx.doi.org/10.1172/JCI117495

[8] Hotamisligil, G.S., Shargill, N.S. and Spiegelman, B.M. (1993) Adipose Expression of Tumor Necrosis Factor-Alpha: Direct Role in Obesity-Linked Insulin Resistance. Science, 259, 87-91. http://dx.doi.org/10.1126/science.7678183

[9] Dobbins, R.L., Szczepaniak, L.S., Bentley, B., Esser, V., Myhill, J. and McGarry, J.D. (2001) Prolonged Inhibition of Muscle Carnitine Palmitoyltransferase-1 Promotes Intramyocellular Lipid Accumulation and Insulin Resistance in Rats. Diabetes, 50, 123-130. http://dx.doi.org/10.2337/diabetes.50.1.123

[10] Kim, J.K., Gavrilova, O., Chen, Y., Reitman, M.L. and Shulman, G.I. (2000) Mechanism of Insulin Resistance in A-ZIP/F-1 Fatless Mice. Journal of Biological Chemistry, 275, 8456-8460. http://dx.doi.org/10.1074/jbc.275.12.8456

[11] Shulman, G.I. (2000) Cellular Mechanisms of Insulin Resistance. Journal of Clinical Investigation, 106, 171-176. http://dx.doi.org/10.1172/JCI10583

[12] Perseghin, G., Scifo, P., De Cobelli, F., Pagliato, E., Battezzati, A., Arcelloni, C., Vanzulli, A., Testolin, G., Pozza, G., Del Maschio, A. and Luzi, L. (1999) Intramyocellular Triglyceride Content Is a Determinant of in Vivo Insulin Resistance in Humans: A 1H-13C Nuclear Magnetic Resonance Spectroscopy Assessment in Offspring of Type 2 Diabetic Parents. Diabetes, 48, 1600-1606. http://dx.doi.org/10.2337/diabetes.48.8.1600

[13] Pan, D.A., Lillioja, S., Kriketos, A.D., Milner, M.R., Baur, L.A., Bogardus, C., Jenkins, A.B. and Storlien, L.H. (1997) Skeletal Muscle Triglyceride Levels Are Inversely Related to Insulin Action. Diabetes, 46, 983-988. http://dx.doi.org/10.2337/diab.46.6.983

[14] Kunesova, M., Braunerova, R., Hlavaty, P., Tvrzicka, E. and Stankova, B. (2006) The Influence of n-3 Polyunsaturated Fatty Acids and Very Low Calorie Diet during a Short-Term Weight Reducing Regimen on Weight Loss and Serum 
Fatty Acid Composition in Severely Obese Women. Physiological Research, 55, 63-72.

[15] Mori, T.A., Bao, D.Q., Burke, V., Puddey, I.B. and Watts, G.F. (1999) Dietary Fish as a Major Component of a Weight-Loss Diet: Effect on Serum Lipids, Glucose, and Insulin Metabolism in Overweight Hypertensive Subjects. The American Journal of Clinical Nutrition, 70, 817-825.

[16] Flachs, P., Mohamed-Ali, V., Horakova, O., Rossmeisl, M. and Hosseinzadeh-Attar, M.J. (2006) Polyunsaturated Fatty Acids of Marine Origin Induce Adiponectin in Mice Fed High-Fat Diet. Diabetologia, 49, 394-397. http://dx.doi.org/10.1007/s00125-005-0053-y

[17] Rustan, A.C., Christiansen, E.N. and Drevon, C.A. (1992) Serum Lipids, Hepatic Glycerolipid Metabolism and Peroxisomal Fatty Acid Oxidation in Rats Fed Omega-3 and Omega-6 Fatty Acids. Biochemical Journal, 283, 333-339. http://dx.doi.org/10.1042/bj2830333

[18] Rossmeisl, M., Macek Jilkova, Z., Kuda, O., Jelenik, T., Medrikova, D., et al. (2012) Metabolic Effects of n-3 PUFA as Phospholipids Are Superior to Triglycerides in Mice Fed a High-Fat Diet: Possible Role of Endocannabinoids. PLoS ONE, 7, e38834. http://dx.doi.org/10.1371/journal.pone.0038834

[19] Lavau, M.M. and Hashim, S.A. (1978) Effect of Medium Chain Triglyceride on Lipogenesis and Body Fat in the Rat. Journal of Nutrition, 108, 613-620.

[20] Wiley, J.H. and Leveille, G.A. (1973) Metabolic Consequences of Dietary Medium Chain Triglycerides in the Rat. Journal of Nutrition, 103, 829-835.

[21] Harkins, R.W. and Sarett, H.P. (1968) Nutritional Evaluation of Medium-Chain Triglycerides in the Rat. Journal of the American Oil Chemists' Society, 45, 26-30. http://dx.doi.org/10.1007/BF02679041

[22] Kaunitz, H., Slanetz, C.A., Johnson, R.E., Babayan, V.K. and Barsky, G. (1958) Relation of Saturated, Medium- and Longchain Triglycerides to Growth, Appetite, Thirst and Weight Maintenance Requirements. Journal of Nutrition, 64, 13-24.

[23] Harris, R.B. (1994) Factors Influencing Energy Intake of Rats Fed either a High-Fat or a Fat Mimetic Diet. International Journal of Obesity and Related Metabolic Disorders, 18, 632-640.

[24] Altunkaynak, Z. (2005) Effects of High Fat Diet Induced Obesity on Female Rat Livers (a Histological Study). European Journal of General Medicine, 2, 100-109.

[25] Straczkowski, M., Kowalska, I., Dzienis-Straczkowska, S., Kinalski, M., Górski, J. and Kinalska, I. (2001) The Effect of Exercise Training on Glucose Tolerance and Skeletal Muscle Triacylglycerol Content in Rats Fed with a High-Fat Diet. Diabetes \& Metabolism, 27, 19-23.

[26] Yasari, S., Paquette, A., Charbonneau, A., Gauthier, M.S., Savard, R. and Lavoie, J.M. (2006) Effects of Ingesting a High-Fat Diet upon Exercise-Training Cease Fat Accretion in the Liver and Adipose Tissue of Rats. Applied Physiology, Nutrition, and Metabolism, 31, 367-375. http://dx.doi.org/10.1139/h06-032

[27] Yasari, S., Dufresne, E., Prud'homme, D. and Lavoie, J.M. (2007) Effect of the Detraining Status on High-Fat Diet Induced Fat Accumulation in the Adipose Tissue and Liver in Female Rats. Physiology \& Behavior, 91, 281-289. http://dx.doi.org/10.1016/j.physbeh.2007.03.012

[28] Horowitz, J.F. and Klein, S. (2000) Lipid Metabolism during Endurance Exercise1,2,3. The American Journal of Clinical Nutrition, 72, 558S-563S.

[29] Katsanos, C.S. (2004) Lipid-Induced Insulin Resistance in the Liver: Role of Exercise. Sports Medicine, 34, $955-965$. http://dx.doi.org/10.2165/00007256-200434140-00002

[30] Schenk, S. and Horowitz, J.F. (2007) Acute Exercise Increases Triglyceride Synthesis in Skeletal Muscle and Prevents Fatty Acid-Induced Insulin Resistance. Journal of Clinical Investigation, 117, 1690-1698. http://dx.doi.org/10.1172/JCI30566

[31] Corcoran, M.P., Lamon-Fava, S. and Fielding, R.A. (2007) Skeletal Muscle Lipid Deposition and Insulin Resistance: Effect of Dietary Fatty Acids and Exercise1,2,3. The American Journal of Clinical Nutrition, 85, 662-677. 